\title{
A Comparative Study Of The Attitudes, Self-Efficacy, And Readiness Of American Versus Turkish Language Teachers
}

\author{
Yesim Ozek Kaloti, MEF University, Turkey
}

\begin{abstract}
Contrasting studies of foreign language teacher education have become a growing interest among educationists and researchers in different countries (Yoder, 1992; McKay \& Montgomery, 1995; Baker \& Giacchino-Baker, 2000; Stachowski \& Sparks, 2007; Firmin, M. W., Firmin, R \& MacKay, F. M., 2008; LaFond \& Dogancay-Aktuna, 2009; Ozek, 2009). Such studies emphasize the importance of comparing and understanding different education programs and enables student teachers to think more globally with respect to their language career. These contrasting studies investigate different aspects of foreign language (FL) teaching programs. The present study reports a comparison of the student teachers of an American and Turkish university regarding their satisfaction and readiness in language teaching, and their attitudes towards language teaching theories and teacher education program. The study aims to discover the teacher trainees' perceptions with an in-depth understanding and compare the differences among them. Therefore, the researcher employed an interconnection of qualitative and quantitative approaches. Data were collected through self-report questionnaires and interviews. The results indicated that there were some significant differences between the subjects in two groups regarding their readiness, their attitudes towards their education programs and their self-perceptions as teacher candidates.
\end{abstract}

Keywords: American vs. Turkish Foreign Language; Teacher Education Programs; Attitudes; Self-Efficacy

\section{THEORETICAL BACKGROUND}

\section{Foreign Language Teaching in the USA}

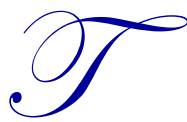

he objectives of teacher education in the USA are not nation-wide in scale as in other countries like Japan, China, England, France, Germany, and Turkey. Each state sets its objectives to meet its specific needs. All institutions must meet the necessary requirements of National Science Education Standards developed by the National Board for Professional Teaching Standards if they wish to offer teaching certificate programs (NRC, 1996: cited in Karamustafaoglu, O. 2009; Karamustafaoglu, Cerrah and Sevim, 2003). In the USA it was enough to be graduated from a two-year undergraduate program to be a teacher as of the early 1980 s in the USA. From then on, teacher education began to be implemented at the undergraduate/postgraduate level. In undergraduate programs, student teachers are required to complete the pre-requisite courses of teaching departments in other faculties in 2 years before graduation. Then they can continue 2 years of teaching programs in the undergraduate study by taking into account their academic history and the interviews. In postgraduate programs, graduate students can enter one-year master's program if they have graduated from a program of 5 years at the teaching department or from the faculty of letters by completing a minor program in teaching if they wish to attend the pro-teach program. They complete the teaching process in the program in at least two full days of practice a week (Demirel, 2000; Karamustafaoglu, 2009).

The USA has become one of the top countries in immigration; 'The number of immigrants (legal and illegal) in the country hit a new record of 40 million in 2010, a 28 percent increase over the total in 2000' (Camarota, 2012). The educational documents reported that the number of people, who are in need of learning English in the USA, increased and the percentages vary from state to state (see Table 1). 
Table 1. Total public school and English language learner, or ELL, population in U.S. states with high proportion of ELLs

\begin{tabular}{l|c|c}
\hline & Total public school population 2009-2010 & Percentage of ELLs \\
\hline California & $6,263,438$ & 28 \\
\hline Florida & $2,634,522$ & 9 \\
\hline Massachusetts & 957,053 & 5 \\
\hline New York & $2,766,052$ & 7 \\
\hline Texas & $4,850,210$ & 15 \\
\hline
\end{tabular}

Although there is a huge demand for language teachers, unfortunately during the last four decades there has been a decline in the number of young men and women majoring in English. 'The numbers changed from 7.6 percent of the majors to 3.9 percent from 1970/71 to 2003/04' (Chace, 2009). The causes of this decline are the rise of the study of business in the nation's colleges and universities or low salaries.

English Language Teaching in Turkey

After WWII, Turkey increased its fascination with Western culture, especially the United States, and the rise of English in Turkey began (Eskicumalı \& Türedi, 2010). English has not been an official language but widely used as a means for communication with others especially Europeans and the rest of the world (Dogancay \& Kiziltepe, 2005). A number of factors have been attributed to the rapid spread of English including Turkey's desire to keep up with the demands of globalization, international trade, and academia, particularly in the areas of math, science, and technology. Following an earlier analysis, Dogancay-Aktuna (1998: 37) summarized the role of English in Turkey as follows:

In Turkey English carries the instrumental function of being the most studied foreign language and the most popular medium of education after Turkish. On an interpersonal level, it is used as a link language for international business and for tourism while also providing a code that symbolizes modernization and elitism to the educated middle classes and those in the upper strata of the socioeconomic ladder.

Since English has received a lot of attention in the country, language teacher education has been revised a number of time. After 1997-1998 reform movement, teacher education programs in Turkey were targeted for change and development and, by all measures (Grossman et al., 2007). With this movement, the renewed teacher education program had some minor modifications in different universities, but the practice part of the internship course was standardized over different Faculties of Education (Seferoglu, 2006). The new program seemed to feed the needs for the qualified teachers in the country.

Although much attention was paid on the language learning and teaching by the national educational system, it has found that Turkish students generally fail to become communicatively competent. In most cases, the reason of this failure has been attributed to the lack of knowledge and practice of teaching methodologies (Tavil, 2012). Therefore, the new teaching program relatively has been decided to focus on the pedagogical competencies of the prospective teachers (teaching theory and teaching practices) in foreign language teaching.

The present study aims to examine the student teachers' beliefs about their teaching programs, their self-beliefs about themselves systems from the student.

\section{METHODOLOGY}

\section{Research Aims}

The present study aims to help the researcher to gain a better understanding of teacher candidates' perceptions about self-efficacy, satisfaction, and readiness in language teaching, their beliefs about language teaching theories and their evaluation of teaching methodology courses in the light of their initial teaching experiences. The study aims to fulfill the following research questions: 
- What are the differences in American and Turkish teacher trainees' self-perceptions about language teaching?

- What are the differences in American and Turkish teacher trainees' beliefs about language teaching and linguistic theories?

- What are these students' attitudes towards their educational programs?

- How well do these trainees feel that they are ready to teach a FL?

\section{Participants}

The sample comprised of 18 student teachers in their final year of studies for a BA degree in the English Language Education Department of a Turkish University in Izmir, and 15 student teachers in their final year of MA TESL program in an American University in Arizona. All subjects participated in an internship program and attended a supervision-training course in their institutions. They reported that they had completed at least one linguistic theory course and one methodology course. This allowed the participants to report their views about the importance of linguistic and language teaching theories in their teaching practice. Convenient sampling collected the data and all subjects participated voluntarily in data collection procedures.

\section{Instruments}

Both quantitative and qualitative research approaches have strengths in their nature. While quantitative research approach aims to discover facts with an objective manner and the results of such research can be generalizable, a qualitative research approach can be designed by verbally and it allows the investigator to search and analyze the human behavior deeply (Katsuko, 1995). The present study aims to discover the teacher trainees' perceptions with an in-depth understanding and compare the differences among them. Therefore the research employed an interconnection of qualitative and quantitative approaches. Data were collected through self-report questionnaires and interviews. There were 21 items in the questionnaires some of which were adopted from a self-report questionnaire designed by LaFond \& Dogancay-Aktuna (2009). The items represented attitudes and self-beliefs of student teachers with regard to different notions about language teaching such as readiness, and self-efficacy in teaching, satisfaction about teacher education program, and general beliefs about teaching. A five-point likert scale ranging from Strongly Agree to Strongly Disagree was used to measure the items. The questionnaires were verbalized and administered to both groups in English. A pilot test had been conducted before the main study was carried out. The test results produced alpha coefficient of 0.78 for the pilot study and 0.86 for the main study.

Interviews were constructed in a semi-structured format and included 9 open-ended questions. The items were addressing 4 main themes:

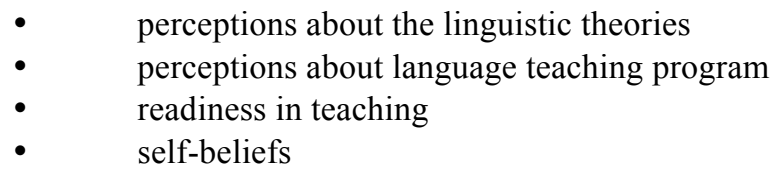

\section{PROCEDURE}

The questionnaires were administered to the student teachers in their class time toward the end of the last term of their academic studies. This would allow them to revise their teaching program and be able to report their perceptions. The subjects were informed that their identities would be kept strictly confidential, and the records of the study would be kept private and used for the research purposes only. The respondents were given 30 minutes to complete the questionnaires.

The interview protocols were conducted after the questionnaires at the subjects' convenience and with their voluntary participation. The researcher while instructors conducted the protocols with the American student teachers and researchers carried out the interviews with the Turkish ones. At the end of the interviews the subjects were 
invited to discuss any issues that were not explained during the interview. The protocols lasted 30-50 minutes and they were audio taped and transcribed by the researcher and her assistants shortly after they were conducted.

\section{DATA ANALYSIS AND RESULTS}

\section{Quantitative Analysis}

The data collected through questionnaires were analyzed using inferential statistics. Since the number of the participants was small in each group, nonparametric tests were used to analyze the data. Table 2 shows the results of Mann-Whitney $\mathrm{U}$ test indicating the main differences between the self-perceptions of the two groups.

The results showed that there were not significant differences between the two groups regarding with the selfperception except for one of the items addressing the teaching ability. It seems that while the student teachers in both groups believed that they had all the knowledge about teaching skills and theories, those in the American group did not see themselves as having the ability to teach as much as those in the Turkish group (Item 19, USA=14, TR $=19.50 ; \mathrm{p} 0,056)$

Regarding the students' beliefs about the linguistic theories, the results revealed that there were not significant differences between the groups in most of the items. The students in both groups seemed to have positive attitudes towards language teaching and linguistic theories except for the item regarding the importance of grammar (Item 12, $\mathrm{USA}=19,87, \mathrm{TR}=14,61 ; \mathrm{p} 0,082$ ). While the American group supported that language teaching should focus on linguistic knowledge, such as theories about grammar, the Turkish group did not agree on this statement.

Finally, the analysis showed some significant differences regarding the subjects' attitudes towards their teaching program. The American group was found to have negative attitudes towards their academic program, while the Turkish group had positive (Item 9 USA=13,87, TR=19,6; p 0,067, Item $13 \mathrm{USA}=12,33$, TR=20,89, p 0,05). The former group believed that their program did not provide enough knowledge and practice in teaching. This seemed to reflect on their feelings about one of the items related to 'readiness in teaching'. The analysis showed that the American student teachers were not ready to start teaching while the Turkish students seemed to be opposite (Item $21 \mathrm{USA}=20,40, \mathrm{TR}=14,17, \mathrm{p}=, 058)$.

Table 2. Mann-Whitney U Test results about the main differences between the two groups' attitudes towards language teaching theories, their self-efficacy and readiness in teaching, and their perceptions about teacher education program.

\begin{tabular}{|c|c|c|c|c|c|c|c|}
\hline \multicolumn{8}{|c|}{ Mann Whitney $U$ test results of American and Turkish student teacher } \\
\hline & & Group & $\mathbf{N}$ & MR & SR & $\mathbf{U}$ & $\mathbf{p}$ \\
\hline 1 & $\mathrm{SP}$ & $\begin{array}{c}\text { USA } \\
\text { TR }\end{array}$ & $\begin{array}{l}14 \\
18\end{array}$ & $\begin{array}{l}15.43 \\
17.33\end{array}$ & $\begin{array}{l}216.00 \\
312.00\end{array}$ & 111 & .524 \\
\hline 2 & LT & $\begin{array}{c}\text { USA } \\
\text { TR } \\
\end{array}$ & $\begin{array}{l}15 \\
18 \\
\end{array}$ & $\begin{array}{l}17.83 \\
16.31\end{array}$ & $\begin{array}{l}267.50 \\
293.50\end{array}$ & 122 & .589 \\
\hline 3 & $\mathrm{R}$ & $\begin{array}{c}\text { USA } \\
\text { TR }\end{array}$ & $\begin{array}{l}15 \\
18 \\
\end{array}$ & $\begin{array}{l}15.80 \\
18.00\end{array}$ & $\begin{array}{l}237.00 \\
324.00\end{array}$ & 117 & .495 \\
\hline 4 & $\mathrm{R}$ & $\begin{array}{c}\text { USA } \\
\text { TR }\end{array}$ & $\begin{array}{l}15 \\
18 \\
\end{array}$ & $\begin{array}{l}18.43 \\
15.81\end{array}$ & $\begin{array}{l}276.50 \\
284.50 \\
\end{array}$ & 113 & .415 \\
\hline 5 & LT & $\begin{array}{c}\text { USA } \\
\text { TR }\end{array}$ & $\begin{array}{l}15 \\
18 \\
\end{array}$ & $\begin{array}{l}16.63 \\
17.31 \\
\end{array}$ & $\begin{array}{l}249.50 \\
311.50\end{array}$ & 129 & .831 \\
\hline 6 & $\mathrm{TP}$ & $\begin{array}{c}\text { USA } \\
\text { TR }\end{array}$ & $\begin{array}{l}15 \\
18 \\
\end{array}$ & $\begin{array}{l}18.33 \\
15.89\end{array}$ & $\begin{array}{l}275.00 \\
286.00\end{array}$ & 115 & .450 \\
\hline 7 & SP & $\begin{array}{c}\text { USA } \\
\text { TR }\end{array}$ & $\begin{array}{l}15 \\
18\end{array}$ & $\begin{array}{l}15.40 \\
18.33\end{array}$ & $\begin{array}{l}231.00 \\
330.00\end{array}$ & 111 & .348 \\
\hline 8 & $\mathrm{R}$ & $\begin{array}{c}\text { USA } \\
\text { TR }\end{array}$ & $\begin{array}{l}14 \\
18\end{array}$ & $\begin{array}{l}13.79 \\
18.61\end{array}$ & $\begin{array}{l}193.00 \\
335.00\end{array}$ & 88 & .117 \\
\hline 9 & $\mathrm{TP}$ & $\begin{array}{c}\text { USA } \\
\text { TR }\end{array}$ & $\begin{array}{l}15 \\
18 \\
\end{array}$ & $\begin{array}{l}13.87 \\
19.61 \\
\end{array}$ & $\begin{array}{l}208.00 \\
353.00 \\
\end{array}$ & 88 & .067 \\
\hline 10 & $\mathrm{SP}$ & $\begin{array}{c}\text { USA } \\
\text { TR }\end{array}$ & $\begin{array}{l}15 \\
18 \\
\end{array}$ & $\begin{array}{l}17.50 \\
16.58 \\
\end{array}$ & $\begin{array}{l}262.50 \\
298.50 \\
\end{array}$ & 127 & .773 \\
\hline
\end{tabular}


(Table 2 Continued)

\begin{tabular}{|c|c|c|c|c|c|c|c|}
\hline \multicolumn{2}{|c|}{ Items } & Group & $\mathbf{N}$ & MR & SR & $\mathbf{U}$ & p \\
\hline 11 & SP & $\begin{array}{c}\text { USA } \\
\text { TR }\end{array}$ & $\begin{array}{l}15 \\
18 \\
\end{array}$ & $\begin{array}{l}17.87 \\
16.28 \\
\end{array}$ & $\begin{array}{l}268.00 \\
293.00 \\
\end{array}$ & 122 & .610 \\
\hline 12 & LT & $\begin{array}{c}\text { USA } \\
\text { TR }\end{array}$ & $\begin{array}{l}15 \\
18 \\
\end{array}$ & $\begin{array}{l}19.87 \\
14.61 \\
\end{array}$ & $\begin{array}{l}298.00 \\
263.00 \\
\end{array}$ & 92 & .082 \\
\hline 13 & $\mathrm{TP}$ & $\begin{array}{c}\text { USA } \\
\text { TR }\end{array}$ & $\begin{array}{l}15 \\
18\end{array}$ & $\begin{array}{l}12.33 \\
20.89\end{array}$ & $\begin{array}{l}185.00 \\
376.00\end{array}$ & 65 & .005 \\
\hline 14 & SP & $\begin{array}{c}\text { USA } \\
\text { TR }\end{array}$ & $\begin{array}{l}15 \\
18\end{array}$ & $\begin{array}{l}16.80 \\
17.17\end{array}$ & $\begin{array}{l}252.00 \\
309.00\end{array}$ & 132 & .903 \\
\hline 15 & SP & $\begin{array}{c}\text { USA } \\
\text { TR }\end{array}$ & $\begin{array}{l}15 \\
18\end{array}$ & $\begin{array}{l}14.00 \\
19.50\end{array}$ & $\begin{array}{l}210.00 \\
351.00\end{array}$ & 90 & .056 \\
\hline 16 & LT & $\begin{array}{c}\text { USA } \\
\text { TR }\end{array}$ & $\begin{array}{l}15 \\
18\end{array}$ & $\begin{array}{l}15.33 \\
18.39\end{array}$ & $\begin{array}{l}230.00 \\
331.00\end{array}$ & 110 & .288 \\
\hline 17 & TP & $\begin{array}{c}\text { USA } \\
\text { TR }\end{array}$ & $\begin{array}{l}15 \\
18\end{array}$ & $\begin{array}{l}17.10 \\
16.92\end{array}$ & $\begin{array}{l}256.50 \\
304.50\end{array}$ & 133 & .953 \\
\hline 18 & $\mathrm{R}$ & $\begin{array}{c}\text { USA } \\
\text { TR }\end{array}$ & $\begin{array}{l}15 \\
18\end{array}$ & $\begin{array}{l}14.43 \\
19.14\end{array}$ & $\begin{array}{l}216.50 \\
344.50\end{array}$ & 96 & .137 \\
\hline 19 & LT & $\begin{array}{c}\text { USA } \\
\text { TR }\end{array}$ & $\begin{array}{l}15 \\
18 \\
\end{array}$ & $\begin{array}{l}18.03 \\
16.14\end{array}$ & $\begin{array}{l}270.50 \\
290.50\end{array}$ & 119 & .540 \\
\hline 20 & SP & $\begin{array}{c}\text { USA } \\
\text { TR }\end{array}$ & $\begin{array}{l}15 \\
18\end{array}$ & $\begin{array}{l}19.67 \\
14.78\end{array}$ & $\begin{array}{l}295.00 \\
266.00\end{array}$ & 95 & .132 \\
\hline 21 & $\mathrm{R}$ & $\begin{array}{c}\text { USA } \\
\text { TR }\end{array}$ & $\begin{array}{l}15 \\
18\end{array}$ & $\begin{array}{l}20.40 \\
14.17\end{array}$ & $\begin{array}{l}306.00 \\
255.00\end{array}$ & 84 & .058 \\
\hline
\end{tabular}

\section{Qualitative Analysis}

The protocols lasted 30-50 minutes and they were audiotaped and transcribed by the researcher shortly after they were conducted. The interviews were evaluated by using content analysis and coding reliability method. The researcher conducted the coding of the interviews independently. The colleagues of the researcher conducted the reliability of the interview protocols' coding. The reliability of the coding process was conducted in two ways. In the intra-rater or test-retest method, the researcher coded the interviews without looking at the results twice. In the independent-coder/inter-rater reliability method, two different researchers (one Turkish and one American) coded the same material independently (Raymond, 1992). The results of the both steps indicated that the coding was reliable (.82 and .78).

The results of the content analysis showed variations between the groups in the regarding with the perceptions about language teaching program, readiness in teaching and self-beliefs. Most of the novice teachers in the American group stated that their program was not successful in the theoretical part and they wished to receive more practice in the college and during the internship program. In one of the interviews for example, the subject stated:

"I felt like our program provided us full of information about theories. However I feel weak when it comes to practice. The program should have provided us more practice on teaching”"

Interestingly, the results indicated that the subjects in the Turkish group had positive feelings about their teaching program. They believed that their program provided them all the knowledge and practice so that they were ready to teach. For example, one of the subjects said:

"I am very glad to learn all the teaching methods because my aim is to be a good teacher. I am very glad with the program. I feel like I can start teaching tomorrow".

Regarding the self-beliefs of subjects, the results were contradicting with the questionnaire results. The subjects in the American group seemed to have positive feelings about themselves and have high self-efficacy in language teaching, while those in the Turkish group seemed to be the opposite. The former group believed that they had all 
the information about classroom management and controlling the students when they had disruptive behaviors, and they were good at motivating students who showed low interest. For example, one of the respondents stated that:

"I know how to deal with problematic students. I have learned all the techniques about this matter. I can easily make any student willing to participate to my lesson".

On the other hand, the latter group seemed to have negative feelings about themselves in language teaching. They did not see themselves as capable in classroom management and controlling and good at motivating students with low interest. For example one of the Turkish teacher candidates said:

"It makes me nervous to think that I should be teaching a big classroom. I cannot cope with the problematic students. I would probably get some help from other teachers".

\section{RESULTS AND DISCUSSION}

This research examines the differences between novice teachers' perceptions about teaching theories and teaching program, self-beliefs, and readiness in teaching. A multi-method research design was used in the study. A qualitative method was conducted to follow up on findings from quantitative data to understand what the figures that came out of the quantitative data analysis actually meant. The aim of the integration of two methods is also to help the researcher to test and determine the opinions, attitudes, and beliefs of a population, and at the same time to examine those beliefs and attitudes from a deeper perspective.

The results complemented each other and revealed that there were some differences between the novice teachers regarding their perceptions about language teaching program and self-beliefs. The results of the quantitative part showed that while Turkish group had high scores in self-perception, attitudes towards teaching program, and readiness in teaching, the American group had high scores in the beliefs about the importance of teaching and linguistic theories.

Interestingly the results of the qualitative part seemed to support some of the results of the quantitative part. It was found that the American student teachers valued the linguistic and teaching theories more than the Turkish student teachers, and they did not see themselves as ready as Turkish student teachers.

This research aims to compare the feelings and perceptions of the novice teachers in different contexts. Therefore it is also important to report here that the aim was not an evaluation of the programs. It would be fair to call for more research in different contexts in these countries to examine the effects of contextual factors on the novice teachers' self-beliefs, attitudes, and expectations about the teaching programs and their future career in teaching.

This research investigated student teachers' perceptions, beliefs about their academic programs and their readiness, based on self-reports and interviews. More objective data could have been collected through classroom observations of the subjects participated in the present study.

Overall, this study is important as an attempt to raise awareness of the importance of comparison of teacher candidates' feelings by using multi-method research design. Studies in longitudinal nature can help one to have a deeper insight about the influence of pre-service teacher education programs and attitudes of novice teachers on their academic achievement across cultures.

\section{ACKNOWLEDGEMENTS}

This paper is based on a research supported by the North Arizona University. Thanks to Prof. William Grabe for his invaluable support and guidance in the research. And thanks to Dr. Kenan Dikilitas who assisted me with collecting surveys and conducting interviews. 


\section{AUTHOR BIOGRPAHY}

Yesim Ozek Kaloti is an Assistant Professor in the Faculty of Education at MEF University, Turkey. She is the Chair of the English Language Teaching Department. Her research interests include all aspects of language learner psychology, in particular, motivation, beliefs, and attitudes. Recently she has become especially interested in the compative studies of teacher education programs in different countries.

\section{REFERENCES}

American Association for the Advancement of Science (AAAS) (2009) Science for all Americans. In O. Karamustafaoglu, 'A comparative analysis of the models of teacher education in terms of teaching practices in the USA, England, and Turkey'. Education, v130 n2 p172-183 Washington, DC: National Academy Press.

Baker, F. J. \& Giacchino-Baker, R. (2000). Building an international student teaching program: A California/Mexico experience. ERIC reproduction: ED449143, 1-17.

Çakıroğlu, J., Çakıroğlu, E., Boone, W. J. (2005). Pre-service teacher selfefficacy beliefs science teaching: a comparison of preservice teachers in Turkey and the USA. http://findarticles.com/p/articles/mi_qa4049/is_200504/ai_n14718070/print

Camarota, S. A. (2012) http://cis.org/2012-profile-of-americas-foreign-born-population

Chace, W. M. 2009. https://theamericanscholar.org/the-decline-of-the-english-department/

Demirel, O. (2000); Karşılaştırmalı Ĕgitim (Comparative Education). Ankara: Pegem Publication

Dogancay-Aktuna, Seran. (1998). 'The Spread of English in Turkey and its Current Sociolinguistic Profile.' Journal of Multilingual and Multicultural Development 19: 3- 39. DOI: 10.1080/01434639808666340

Dogancay-Aktuna, S. \& Kiziltepe, Z. (2005). 'English in Turkey', World Englishes, Vol. 24, No. 2, pp. $253-265$. http://staff.neu.edu.tr/ cise.cavusoglu/status\%20of\%20English\%20in\%20Turkey.pdf

Eskicumal, A. \& Türedi, H. (2010). The rise of English teaching in Turkish curriculum. International Online Journal of Educational Sciences, 2(3), 738-771. http://www.iojes.net/userfiles/Article/IOJES_390.pdf

Firmin, M. W., Firmin. R, \& MacKay, F. M., (2008). 'Extra Curricular Life Of Overseas Student-Teachers', http://psych.iupui.edu/sites/default/files/firmin.ruthie._cv._research_8.11.14.pdf

Grossman, G. M., Onkol, P. E. and Sands, M. (2007) Curriculum reform in Turkish teacher education: Attitudes of teacher educators towards change in an EU candidate nation. International Journal of Educational Development 27, 138-150 doi: 10.1016/j.ijedudev.2006.07.005

Karamustafaoğlu, O., Cerrah, L., \& Sevim, S., (2003) "Improving of Science Education Curriculum In The World and Turkey: A Short View", Energy, Education, Science \& Technology, 11 (2), 75-79. http://www.slideshare.net/efedincer/eitimdeteknoloji-okuryazarligı

Karamustafaoglu, O. (2009). A comparative analysis of the models of teacher education in terms of teaching practices in the USA, England, and Turkey. http://eric.ed.gov/?id=EJ871652

Katsuko, H. (1995) Quantitative and qualitative research approaches in education, http://findarticles.com/p/articles/mi_qa3673/is_n3_v115/ai_n28656082/pg_3/?tag=mantle_skin;content.

LaFonda \& Dogancay-Aktuna, (2009); 'Teacher perspectives on linguistics in TESOL teacher education', Language Awareness, Vol. 18, No. 3-4, August-November 2009, 345-365. DOI: 10.1080/09658410903197348

McKay, J. W., \& Montgomery, J. (1995). Changes in perceptions: A comparative study of the experiential learning of international student teachers. Paper presented at the annual meeting of the American Educational Research Association, San Francisco, CA. http://files.eric.ed.gov/fulltext/ED384582.pdf

National Research Council (NRC) (2009). 'National science education standards'. In O. Karamustafaoglu, 'A comparative analysis of the models of teacher education in terms of teaching practices in the USA, England, and Turkey'. Education, v130 n2 p172-183, EJ871652. Washington, DC: National Academy Press.

Ozek, Y. (2009); Overseas teaching experience: student teachers' perspectives of teaching practicum. Procedia - Social and Behavioral Sciences. Volume 1, Issue 1, 2009, Pages 2541-2545. DOI: 10.1016/j.sbspro.2009.01.448

Raymond, G. (1992). Basic Inteviewing Skills. Itasca, IL: F. E. Peacock.

Seferoglu, G. (2006), Teacher candidates' reflections on some components of a pre-service English teacher education program in Turkey, Journal of Education for Teaching, Vol. 32, No. 4, November 2006, pp. 369-378). DOI 10.1080/02607470600981953

Stachowski, L. L.\& Tyler, S., (2007). Thirty Years and 2,000 Student Teachers Later: An Overseas Student Teaching Project That Is Popular, Successful, and Replicable, Teacher Education Quarterly, 34(1), 115-132.

Tavil, Z. M. (2012) 'The Program of Pedagogical Courses at an English Language Teaching Department: A Summative Evaluation', Atatürk Üniversitesi Sosyal Bilimler Enstitüsü Dergisi 16 (2): 189-200

U.S. Department of Education, National Center for Educational Statistics, "Local Education Agency Universe Survey", 2009-10 Core of Common Data. http://nces.ed.gov/ccd/pdf/INsc09101a.pdf

Yal, L. (2011)_http://laurenyal.myefolio.com/Uploads/Teaching\%20EFL\%20in\%20Turkey.pdf 
Yoder, J. et.al. (1992) 'Elements of 'Good Teaching': A Comparison of Education Students' Perceptions in Botswana, Finland, California, \& Zimbabwe'. Paper presented at the Annual Conference of the Comparative and International Education Society. Maryland.

Letters: Low salary deters men from teaching. http://usatoday30.usatoday.com/news/opinion/letters/story/2012-08-19/maleteachers-elementary-school/57145422/1 